\title{
Determinan Keikutsertaan Ibu Sebagai Akseptor Metode Kontrasepsi Jangka Panjang Pasca Persalinan (Studi Kasus di Fasilitas Kesehatan Tingkat Lanjutan Kabupaten Dharmasraya)
}

\author{
Sri Andar Puji Astuti ${ }^{*}$, Edison ${ }^{2}$, Pom Harry Satria ${ }^{3}$ \\ Pendidikan IImu Kebidanan Pascasarjana Fakultas Kedokteran Universitas Andalas ${ }^{1}$ \\ Bagian IImu KesehatanMasyarakat Fakultas Kedokteran Universitas Andalas ${ }^{2}$ \\ Bagian Obstetri dan Gynecologi Fakultas Kedokteran Universitas Andalas ${ }^{3}$ \\ Email : sriandarpuji@gmail.com, edison.dokter@gmail.com, harrysatria pom@yahoo.com
}

\begin{abstract}
Postpartum family planning programs are effective and efficient measures to reduce maternal mortality and infant mortality due to unwanted pregnancies which have the potential to cause direct maternal death (abortion, eclampsia and prolonged labor) and indirectly to one component "4 Too "(too young, too old, too much and too close). The Sungai Dareh is the only advanced health facility in Dharmasraya Regency in Dharmasraya Regency with acceptors of long-term contraceptive method acceptors in a very slow or stagnant condition. The purpose of this study was to determine the most dominant factors related to the participation of postpartum mothers using long-term contraceptive methods. The research design was cross sectional. Primary data is taken during 2017 , which is between February and Desember with a sample of 99 people in the Maternity Room at the regional public hospital Sungai Dareh. The analysis model used is a regression of the backward likelihood ratio method. The sampling technique uses purposive sampling. Based on the test results, the variables of poverty level, number of surviving children, health status, age level of respondents, level of education, purpose of using family planning methods, husband support and attitudes have a significant relationship with the participation of postpartum long-term contraceptive methods. While unrelated factors are the age of first marriage and the level of knowledge of the respondents. From the regression model produced, husband's support is the most dominant factor $(p=0.001$, OR = 19.591 (95\% Cl: 3.227 - 118.927), so it can be concluded that husband's support influences the wife's decision in the participation of the postpartum contraceptive method.
\end{abstract}

Keywords:

Participation; long-term contraceptive methods; postpartum

\section{PENDAHULUAN}

Angka Kematian lbu (AKI) menjadi salah satu indikator penting derajat kesehatan masyarakat. Saat ini status kesehatan ibu dan anak di Indonesia masih jauh dari yang diharapkan, ditandai dengan masih tingginya AKI Berdasarkan Survey Demografi dan Kesehatan Indonesia (SDKI) 2012 sebesar 359/100.000 kelahiran hidup. Angka ini masih cukup tinggi jika dibandingkan dengan negaranegara di kawasan ASEAN (Association of Southeast Asian Nation). Pada tahun 2007, ketika AKI di Indonesia mencapai 228, AKI di Singapura hanya 6/100.000 kelahiran hidup, Brunei 33/100.000 kelahiran hidup, Filipina 112/100.000 kelahiran hidup, serta Malaysia dan Vietnam sama-sama mencapai 160/100.000 kelahiran hidup (Kementerian Kesehatan, 2014).

Tingginya kematian ibu dan bayi tidak terlepas dari masih tingginya angka KTD (kehamilan tidak diinginkan) mencapai 16,8\% yang berkaitan dengan tingginya angka aborsi. Aborsi sendiri memberikan kontribusi terhadap kematian ibu sampai 13\%. Selain itu, masih banyak ditemukan kehamilan yang tidak ideal (terlalu banyak, terlalu muda, terlalu tua, dan terlalu dekat jarak kelahiran), yang sangat membahayakan bagi kesehatan ibu atau lebih dikenal sebagai "4 Terlalu (4 T) (Kementerian Kesehatan RI, 2013).

Keterkaitan manfaat KB dengan penurunan AKI melahirkan seringkali tidak dirasakan. Salah satu penyebab AKI antara lain karena masih rendahnya pemahaman tentang $\mathrm{KB}$ dan rendahnya akses terhadap pelayanan KB pada masa pasca persalinan (Kementerian Kesehatan RI, 2013).

Pemberian metode KB selama masa pasca persalinan dapat meningkatkan kesadaran lbu untuk menggunakan kontrasepsi. Hal ini dikarenakan pada sebagian wanita setelah melahirkan biasanya tidak menginginkan kehamilan atau menunda kehamilan sampai 24 bulan setelah melahirkan tetapi mereka tidak menggunakan alat kontrasepsi (unmet need sehingga akan berpotensi besar untuk terjadinya KTD (Utami et al, 2013).

KTD pada ibu pasca persalinan, akan dihadapkan pada dua hal yang sama-sama berisiko. Pertama, jika kehamilan diteruskan, maka kehamilan tersebut akan berjarak sangat dekat dengan kehamilan sebelumnya, yang merupakan salah satu komponen "4 Terlalu". Keadaan ini akan menjadi kehamilan yang berisiko terhadap terjadinya komplikasi dalam kehamilan, persalinan dan nifas berikutnya yang 
dapat berkontribusi terhadap kematian ibu (dan juga kematian bayi). Kedua, jika kehamilan diakhiri (aborsi, terutama jika dilakukan dengan tidak aman), maka berpeluang untuk terjadinya komplikasi aborsi yang juga dapat berkontribusi terhadap kematian ibu. Oleh sebab itu, KB pasca persalinan merupakan suatu upaya strategis dalam penurunan AKI, juga AKB (Kementerian Kesehatan RI, 2013).

Berdasarkan Laporan Hasil Pelayanan Kontrasepsi Januari-Juli 2013 (BKKBN), cakupan KB Pasca Persalinan dan Pasca Keguguran dibandingkan dengan cakupan peserta KB Baru masih sebesar 13,27\%. Capaian tersebut juga masih didominasi oleh non MKJP yaitu suntikan $(52,49 \%)$ dan pil $(18,95 \%)$, sementara capaian MKJP implan $(8,08 \%)$, IUD (14,06\%), MOW (3,27\%) dan MOP $(0,02 \%)$. Prevalensi MKJP di Provinsi Sumatera Barat pun menunjukkan lebih rendah dengan rata-rata nasional yaitu $14.4 \%$ dari target nasional yaitu $<65,5 \%$. Oleh sebab itu, melalui kontrasepsi pasca persalinan ini menjadikan setiap ibu bersalin mendapatkan kontrasepsi yang lebih diarahkan pada MKJP sehingga dapat mencegah terjadinya missed opportunity, menurunkan unmeet need dan mendukung percepatan penurunan AKI (Kementerian Kesehatan RI, 2013).

Berdasarkan laporan dibidang kesehatan keluarga Dinas Kesehatan Kabupaten Dharmasraya bahwa masyarakat lebih banyak menggunakan Non MKJP dengan alat kontrasepsi terbanyak yaitu suntik dengan jumlah 13.441 atau $(53,6 \%)$ dibandingkan sedangkan MKJP hanya 25,4\%. Selanjutnya dijelaskan bahwa perbandingan ibu yang memakai kontrasepsi pasca persalinan dibandingkan dengan jumlah ibu bersalin baik normal maupun sectio caesarea sekitar $3: 10$ atau dengan kata lain dari setiap 10 ibu bersalin hanya 3 ibu yang menggunakan kontrasepsi pasca persalinan di RSUD Sungai Dareh. Perbandingan tersebut telah dihitung dalam kurun waktu selama 8 bulan yaitu JanuariAgustus 2016 (Dinas Kesehatan Kabupaten Dharmasraya, 2014).

Walaupun semua metode kontrasepsi dapat digunakan selama pasca persalinan, namun mengingat drop out (DO) yang cukup tinggi dalam penggunaan non MKJP, maka dalam memberikan pelayanan konseling klien diarahkan untuk memilih MKJP (Metode Kontrasepsi Jangka Panjang), seperti implant, IUD (Intra Uterine Device), MOP (Metode Operasi Pria) dan MOW (Metode Operasi Wanita). Dengan MKJP, angka ketidak berlangsungan kontrasepsi diharapkan dapat ditekan atau dikurangi (Kementerian Kesehatan RI, 2013).
Berdasarkan uraian di atas peneliti tertarik untuk melakukan penelitian tentang determinan keikutsertaan ibu sebagai akseptor metode kontrasepsi jangka panjang pasca persalinan di Fasilitas Kesehatan Tingkat Lanjutan Kabupaten Dharmasraya dengan tujuan diketahuinya faktor yang yang paling menentukan atau dominan berhubungan dengan keikutsertaan ibu KB MKJP Pasca Persalinan di RSUD Sungai Dareh. Hasil penelitian ini memiliki beberapa manfaat antara lain :

1. Dapat dijadikan sebagai bahan pertimbangan untuk membuat kebijakan yang berkaitan dengan KB pasca persalinan yang disesuaikan dengan berbagai permasalahan di lapangan.

2. Memperbaiki program KB pasca persalinan dengan cara meningkatkan hubungan kerjasama yang terjalin antara pihak Pemerintah Daerah, BP3A KB dan RSUD Sungai Dareh

3. Memberikan informasi serta masukan terkait pelayanan KB pasca persalinan di RSUD Sungai Dareh sehingga kedepan dapat melaksanakan pelayanan lebih efektif dan efisien sesuai dengan tuntutan dan harapan masyarakat yang akan dilayani.

\section{METODE PENELITIAN}

Jenis penelitian ini adalah analytic dengan pendekatan disain cross sectional study yaitu peneliti melakukan observasi atau pengukuran determinan keikutsertaan ibu sebagai akseptor MKJP pasca persalinan di Kamar Bersalin RSUD Sungai Dareh. Penelitian ini menggunakan pendekatan kuantitatif. Sumber data primer menggunakan instrumen kuesioner penelitian yang telah diuji validitas dan reliabilitas dengan rumus berturut-turut adalah product moment dan cronbach's alpha. Pengujian tersebut dilaksanakan pada orang yang yang memiliki karakteristik sama dengan sample.

Teknik pengambilan sampel menggunakan purposive sampling Jumlah sampel penelitian adalah 99 orang. Penelitian ini merupakan penelitian noneksperimen dengan desain survei menggunakan pendekatan kuantitatif dengan statistik inferensial. Analisis statistik yang digunakan adalah analisis regresi metode backward likelihood ratio.

\section{HASIL DAN PEMBAHASAN}

RSUD Sungai Dareh merupakan Fasilitas Kesehatan Tingkat Lanjutan (FKTL) yang merupakan pelayanan kesehatan rujukan satusatunya milik pemerintah daerah di Kabupaten Dharmasraya. Pelayanan KB pasca persalinan telah dimulai semenjak program jaminan persalinan pada tahun 2011 akan tetapi diperoleh permasalahan yaitu jumlah 
akseptornya mengalami penurunan secara bertahap seiring perubahan kebijakan dari Kementerian Kesehatan yaitu program Jampersal (Jaminan Persalinan) menjadi program JKN-KIS (Jaminan Kesehatan Nasional-Kartu Indonesia Sehat). Berdasarkan analisis data maka diperoleh beberapa data pada tabel 1 berikut :

Table 1. Hasil Analisis Univariat dan Bivariat

\begin{tabular}{|c|c|c|c|}
\hline \multicolumn{2}{|c|}{ Variabel } & \multirow{2}{*}{$\begin{array}{c}\% \\
20,2\end{array}$} & \multirow[t]{2}{*}{ P Value } \\
\hline Keikutsertaan & Ikut & & \\
\hline & Tidak ikut & 79,8 & - \\
\hline \multirow[t]{2}{*}{ Tingkat Kemiskinan } & Tidak miskin & 51,5 & \\
\hline & Miskin & 48,5 & 0,019 \\
\hline \multirow[t]{2}{*}{ Jumlah Anak Hidup } & Banyak & 47,5 & \\
\hline & Sedikit & 52,5 & 0,024 \\
\hline \multirow[t]{2}{*}{ Status Kesehatan } & Sehat & 59,6 & \\
\hline & Tidak sehat & 40,4 & 0,019 \\
\hline \multirow[t]{2}{*}{ Usia } & Beresiko & 41,7 & \\
\hline & Tidak Beresiko & 58,3 & 0,044 \\
\hline \multirow[t]{2}{*}{ Pendidikan } & Tinggi & 55,6 & \\
\hline & Rendah & 44,4 & 0,027 \\
\hline \multirow[t]{2}{*}{ Tujuan pakai KB } & Menunda $>2$ tahun & 75,8 & \\
\hline & Tidak ingin anak lagi & 24,2 & 0,003 \\
\hline \multirow[t]{2}{*}{ Usia nikah Pertama } & Beresiko & 49,5 & \\
\hline & Tidak Beresiko & 50,5 & 0,147 \\
\hline \multirow[t]{2}{*}{ Pengetahuan } & Tinggi & 27,3 & \\
\hline & Rendah & 72,7 & 0,759 \\
\hline \multirow[t]{2}{*}{ Dukungan suami } & Mendukung & 38,4 & \\
\hline & Tidak mendukung & 61,6 & 0,001 \\
\hline \multirow[t]{2}{*}{ Sikap } & Positif & 55,6 & \\
\hline & Negatif & 44,4 & 0,027 \\
\hline
\end{tabular}

Sumber : Data Primer

Berdasarkan tabel 1 diatas terlihat bahwa sebagian besar $(79,8 \%)$ ibu tidak ikut KB MKJP serta memiliki jumlah anak $\leq 2$ orang (52,5\%). Lebih dari separo responden sehat $(59,6 \%)$ yang artinya bahwa pada saat kegiatan penelitian tidak memiliki satupun kontra indikasi relative maupun absolut ikut pada program KB MKJP Pasca persalinan. Selain itu, usia menikah pertama ibu maupun usia responden saat penelitian sebagian besar tidak beresiko serta memiliki sikap yang positif (55,6\%). Selanjutnya, tingkat pendidikan terbanyak adalah tinggi atau lulus SMA sejumlah (55,6\%) dan memilih menunda kehamilan $>2$ tahun sebagai tujuan mengikuti KB (75,8 \%). Akan tetapi, tingkat pengetahuan masih dalam kategori rendah $(72,7 \%)$ dan tidak mendapatkan dukungan suami $(61,6 \%)$.

Berdasarkan hasil analisis bivariat dari 10 variabel yang diuji menggunakan rumus chi square, didapatkan 8 variabel yang memiliki hubungan dengan keikutsertaan KB MKJP pasca persalinan karena memiliki $p$ value $<0,05$. Variabel tersebut antara lain : tingkat kemiskinan, jumlah anak yang masih hidup, status kesehatan, tingkat pendidikan, tingkat usia responden, tujuan menggunakan KB, tingkat dukungan suami dan sikap. Sedangkan 2 variabel yang tidak memiliki hubungan adalah variabel usia pertama menikah dan pengetahuan responden karena memiliki $p$ value $>0,05$.

Menurut Dewi dan Notobroto (2014) pendidikan merupakan faktor yang sangat menentukan pengetahuan dan persepsi seseorang terhadap pentingnya suatu hal, termasuk dalam pemilihan metode kontrasepsi. Faktor pendidikan juga menentukan dalam pola pengambilan keputusan dan penerima informasi, semakin berpendidikan seseorang maka keputusan yang diambil akan semakin baik.

Sedangkan menurut Notoatmodjo (2003), tingkat pengetahuan seseorang dapat berpengaruh terhadap sikap, persepsi, motivasi kemantapan dan perilaku seseorang yang dalam hal ini adalah keikutsertaan ibu sebagai akseptor MKJP pasca persalinan. Jika seseorang tersebut mempunyai pengetahuan yang baik tentang manfaat maupun akibat jika tidak menggunakan MKJP pasca persalinan maka akan menggunakan pengetahuan tersebut sebagai dasar terbentuknya tindakan dengan segera ikut menjadi akseptor MKJP pasca persalinan.

RSUD Sungai Dareh merupakan satusatunya FKTL di Kabupaten Dharmasraya dan di rumah sakit ini lebih banyak pasien datang sudah dalam kondisi gawat darurat baik maternal maupun neonatal dibandingkan dengan pasien yang memiliki riwayat kegawatdaruratan sehingga jika seseorang tersebut mempunyai pengetahuan yang baik sebelumnya maka orang tersebut akan ikut serta KB MKJP pasca persalinan. Pendapat tersebut sesuai dengan Indrawati (2011) pertimbangan akseptor dalam menentukan pilihan jenis kontrasepsi tidak hanya karena terbatasnya metode yang tersedia, tetapi juga kurangnya pengetahuan tentang kesesuaian alat kontrasepsi dengan tujuan penggunaan (kebutuhan), persyaratan dan keamanan metode kontrasepsi tersebut, tempat pelayanan dan 
kontraindikasi alat kontrasepsi yang bersangkutan. Pemahaman keluarga tentang kesehatan reproduksi termasuk pemilihan alat kontrasepsi dipengaruhi oleh faktor pendidikan, pendapatan, pengetahuan, serta tingkat pemahaman kesehatan reproduksi.

Faktor lain yang uga akan mempengaruhi keikutsertaan ibu pada KB MKJP pasca persalinan adalah pengaruh keluarga sehingga semakin baik pengetahuan anggota keluarga tentang manfaat kontrasepsi pasca persalinan maka akan keluarga pendamping akan merespon, memberi dukungan serta menyetujui penggunaan kontrasepsi (Suparyanto, 2011). Selanjutnya, analisis Multivariat diperoleh hasil seperti pada tabel 2 berikut :

Tabel 2. Hasil Analisis Multivariat

\begin{tabular}{llll}
\hline \multicolumn{1}{c}{ Variabel } & P value & OR & \multicolumn{1}{c}{$\mathbf{9 5} \% \mathbf{C l}$} \\
\hline Pendidikan & 0,007 & 20,862 & $2,303-188,959$ \\
Kemiskinan & 0,002 & 21,033 & $2,992-147,875$ \\
Dukungan Suami & 0,001 & 19,591 & $3,227-118,927$ \\
Jumlah Anak hidup & 0,003 & 0,063 & $0,010-0,394$ \\
Status Kesehatan & 0,024 & 7,565 & $1,311-43,658$ \\
\hline
\end{tabular}

Berdasar tabel 2 diatas terlihat bahwa variabel yang berhubungan paling dominan adalah variabel dukungan suami karena $p$ value 0,001 dengan OR adalah 19,591 (Cl $95 \%$ : 3,227 - 118,927) artinya ibu yang tidak mendapatkan dukungan suami beresiko 19,591 kali tidak akan ikut sebagai akseptor KB MKJP pasca persalinan dibandingkan dengan ibu yang mendapatkan dukungan suami. Sedangkan variabel yang lainnya berperan sebagai variabel konfounding.

Suparyanto (2011) berpendapat bahwa dalam melaksanakan keluarga berencana, dukungan suami sangat diperlukan. Seperti diketahui bahwa di Indonesia, keputusan suami dalam mengizinkan istri adalah pedoman penting bagi istri untuk menggunakan alat kontrasepsi. Bila suami tidak mengizinkan atau mendukung, hanya sedikit istri yang berani untuk tetap memasang alat kontrasepsi tersebut. Dukungan suami sangat berpengaruh besar dalam pengambilan keputusan menggunakan atau dipengaruhi oleh faktor sosial budaya.

Menurut Friedman (2010) dukungan suami merupakan salah satu faktor penguat (reinforcing factor) yang dapat mempengaruhi seseorang dalam berperilaku. Sedangkan dukungan suami dalam KB merupakan bentuk nyata dari kepedulian dan tanggung jawab para pria. Aspek-aspek dukungan dari keluarga (suami) ada empat aspekyaitu dukungan emosional, informasi, instrumental dan penghargaan

Menurut Gudaynhe dkk (2014), Salah satu hal yang memberikan peluang akseptor untuk menggunakan MKJP adalah berdiskusi dengan pasangan/suami. Pada penelitian ini diperoleh hasil uji univariate terbanyak $(61,6 \%)$ tidak mendapat dukungan suami.

Suami memiliki kontribusi yang besar dalam mempengaruhi keputusan seorang istri dalam keikutsertaan program KB. Sebuah rumah tangga yang terdiri dari suami, istri dan anak, maka suami akan menjadi orang pertama yang berpengaruh terhadap berbagai pengambilan keputusan karena suami dipandang sebagai kepala keluarga, pelindung keluarga, pencari nafkah dan seseorang yang dapat membuat keputusan dalam suatu keluarga sehingga pengetahuan yang memadai tentang alat kontrasepsi dapat memotivasi suami menganjurkan istrinya ikut serta dalam KB MKJP pasca persalinan. Selain itu, faktor berdiskusi istri dengan suami akan memberikan peluang bagi istri untuk menggunakan metode kontrasepsi (BKKBN, 2013).

Data Badan Koordinasi Keluarga Berencana Nasional (BKKBN) menyebutkan kondisi pemilihan kontrasepsi saat ini yang berkaitan dengan kesetaraan dan keadilan gender dalam keluarga berencana $16 \%$ suami tidak ingin menjadi peserta KB dan pengambil keputusan penggunaan metode ber-KB masih didominasi suami seumlah $60 \%$, (Maryatun, 2011).

Penelitian Paskaria (2015) memperoleh hasil yang sejalan dengan penelitian ini yaitu ada hubungan antara peran suami dengan status penggunaan MKJP. Penelitian tersebut memperoleh kesimpulan bahwa peran suami memberikan peluang 11,9 kali bagi istri untuk menggunakan MKJP. Dominasi suami sebagai pengambil keputusan untuk menjadi peserta KB bagi istri juga dapat dipengaruhi karena terbatasnya pengetahuan suami tentang KB dan kesehatan reproduksi serta anggapan yang salah bahwa suami pengambil keputusan dalam keluarga dan KB hanya merupakan urusan perempuan. Pentingnya pria dilibatkan dalam KB dan kesehatan reproduksi didasarkan bahwa pria adalah mitra reproduksi dan seksual, sehingga sangat beralasan apabila pria dan wanita berbagi tanggung jawab dan peran secara seimbang untuk mencapai kepuasan kehidupan seksual dan berbagi beban untuk mencegah penyakit serta komplikasi kesehatan reproduksi.

Pria bertanggung jawab secara sosial dan ekonomi termasuk untuk anak-anaknya sehingga keterlibatan pria dalam keputusan 
reproduksi akan membentuk ikatan yang lebih kuat diantara mereka dan keturunanya. Pria secara nyata terlibat dalam fertilitas dan mereka mempunyai peranan yang penting dalam memutuskan kontrasepsi yang akan digunakan istrinya serta dukungan kepada pasanganya terhadap kehidupan reproduksinya seperti saat dan setelah melahirkan serta selama masa menyusui (Maryatun, 2011).

\section{SIMPULAN}

Faktor yang paling dominan menentukan keikutsertaan ibu dalam KB MKJP Pasca persalinan adalah dukungan suami sehingga perlu kerja keras pemerintah Kabupaten Dharmasraya maupun penyelenggara di setiap fasilitas kesehatan dalam memaksimalkan peran suami dengan cara :

1. Memberikan informasi lengkap tentang $\mathrm{KB}$ MKJP pasca persalinan kepada suami sehingga diharapkan dapat memberi dukungan kepada istri berupa saran, pengarahan dan umpan balik tentang $\mathrm{KB}$ MKJP pasca persalinan.

2. Memberikan informasi kepada keluarga pasien tentang menfaat KB MKJP pasca persalinan karena keintiman hubungan sosial dalam keluarga dapat berpengaruh terhadap keputusan dukungan suami

3. Suami perlu memberikan dukungan secara langsung kepada istri berupa pemberian nasehat, petunjuk, saran atau umpan balik yang diper oleh dari tenaga kesehatan, sehingga istri termotivasi menggunakan KB, memberikan dukungan sosial berupa perhatian dan keperdulian dengan cara mengantarkan dan menunggu istri mendapatkan pelayanan KB MKJP pasca persalinan.

\section{DAFTAR PUSTAKA}

Affandi B, Erjan A. (2012). Buku Panduan Praktis Pelayanan Kontrasepsi. Jakarta : PT Bina Pustaka Sarwono Prawirohardjo

Badan Pusat Statistik Kabupaten Dharmasraya. 2016. Dharmasraya Dalam Angka. BPS Kabupaten Dharmasraya

Afrizal. (2014). Metode Penelitian Kualitatif. Jakarta : PT Raja Grafindo Persana.

BKKBN Puslitbang Keluarga Berencana Dan Keluarga Sejahtera. (2013). Pemantauan Pasangan Usia Subur Melalui Mini Survey Indonesia. Jakarta.

BKKBN. (2017). Laporan Kinerja Instansi Pemerintah 2016 Badan Kependudukan dan Keluarga Berencana Nasional.

Dewi, P.H \& Notobroto, H.B. 2014. Rendahnya keikutsertaan Pengguna Metode Kontrasepsi Jangka Panjang Pada Pasangan Usia Subur. Jurnal FKM UNAIR Vol 3(1), pp. 66-72
Dinas Kesehatan Kabupaten Dharmasraya. (2014). Profil Dinas Kesehatan

Friedman, M. 2010. Buku Ajar Keperawatan keluarga : Riset, Teori, dan Praktek. Edisi ke-5. Jakarta: EGC

Gudaynhe. Shimels W. 2014. Facctors Affecting the use of Long-Acting Reversible Contraceptive Methods Among Married Women in Debre Markos Town, North West Ethiophia 2013.Global Journal of Medical Research : Gynechologi and Obstetric, Vol 14 (5) Version 1.0 year 2014

Handayani, S. 2010. Buku Ajar Pelayanan keluarga berencana.AHM Yogyakarta : Pustaka Rihama

Hartoyo. Melly, L. Sri, R. (2011). Studi Nilai Anak, Jumlah Anak Yang diinginkan, dan Keikutsertaan Orang Tua dalam Program KB. Jurnal IImu Keluarga dan Konsumen, Vol 4(1), pp. 37-45

Hidayat, A. (2009). Metode Penelitian Kebidanan Teknik Analisis Data. Jakarta : Salemba Medika

Indrawati, F. Mahmudah, LTS. (2015). Analisis Faktor yang Berhubungan Dengan Pemilihan Metode Kontrasepsi Jangka Panjang (MKJP) Pada Wanita Akseptor KB Wanita di Kenyamatan BanyuBiru Kabupaten Semarang. Unnes Journal of Public Health, Vol 4(3)

Isfandari, S. Selma, S. Lamria,P. Dina, B. (2015). Kontribusi Penggunaan Kontrasepsi Hormonal Terhadap Perbedaan Prevalensi Hipertensi Perempuan dan Lelaki di Indonesia : Perspektif Jender Riskesdas 2013. Buletin Penelitian Kesehatan, Vol 44(1), pp. 33-40

Isa (2009). Determinan Unmet Need Keluarga Berencana di Indonesia Analisis Data SDKI 2007. Jakarta : Universitas Indonesia

Juliaan, S. Maria. (2015). Penggunaan Kontrasepsi Pada Wanita Pasca Melahirkan dan Pasca Keguguran, SDKI 2012.Juliastuty, D. Setyowati. Yati, A. (2008). Pengambilan Keputusan Pemakaian Kontrasepsi Pada Ibu Grande Multipara di Kabupaten Tangerang : Studi Grounded Theory. Jurnal Keperawatan Indonesia, Vol 12(2), pp. 100-107

Kementerian Kesehatan Republik Indonesia. (2013). Profil Kesehatan Indonesia 2012. Jakarta : Kementrian Kesehatan Republik Indonesia.

Kementerian Kesehatan RI. (2015). Profil Kesehatan Indonesia 2014. Jakarta : Kementrian Kesehatan RI.

Kementerian Kesehatan RI. (2013). Situasi Keluarga Berencana di Indonesia. Buletin 
Jendela Data \& Informasi Kesehatan. Volume 2, Semester 2.

Notoatmodjo, S. (2003). Pendidikan dan Perilaku Kesehatan. Jakarta : PT Rineka Cipta.

(2010). IImu Perilaku Kesehatan. Jakarta : PT Rineka Cipta.

Okech, T C., Nelson W. Wawire. Tom K. Mburu. (2011). Contraceptive Use Among Women Reproductive Age In Kenya's City Slums. International Journal Of Business and Social Science, Vol 2(1), pp. 22-43

Paskaria, C. 2015. Faktor-faktor non medis yang mempengaruhi penggunaan MKJP pada wanita pascasalin di Indonesia. Journal of Medicine and Health Vol 1(2) Agustus 2015

A.G.D.Pramono. Nurullita U, S. Rejeki. 2012. Analisis Faktor-Faktor yang Mempengaruhi Pemilihan Alat Kontrasepsi Wanita (Studi Kasus di Desa Toggara Kecamatan Kedung Banteng Kabupaten Tegal). Media Statistika $3(1): 40$

Saskara, I. (2015). Pengaruh Faktor Sosial, Ekonomi, dan Demografi Terhadap Penggunaan Kontrasepsi di Denpasar. Jurnal Ekonomi Kuantitatif Terapan 8 (2) : 156-161

Satroasmoro, S. (2011). Dasar-dasar Metodologi Penelitian Klinis Edisi ke-4. Jakarta : CV. Sagung Seto

Setiadi. Lilik, I. (2015). Pengambilan Keputusan Penggunaan Alat Kontrasepsi latri dalam Keluarga. Populasi, Vol 23(21), pp. 20-35

Singarimbun, M. Sofian, E. 2006. Metode Penelitian Survey (Editor). Jakarta : LP3ES

Sugiyono. (2013). Cara Mudah Menyusun : Skripsi, Tesis dan Disertasi. Bandung : Alfabeta.

Sugono, D. (2008). Kamus Bahasa Indonesia. Jakarta : Pusat Bahasa Departemen Pendidikan Nasional.

Suparyanto. 2011. Wanita Usia Subur. Wordpress. Com Diakses tanggal 19 Oktober 2011

Teffera, AS. Wondifraw, Abebach, A. 2015. Determinants of long acting contraceptive use among reproductive age women in Ethiopia : Evidence from EDHS2011. Science Journal of public Health 2015; 3 (1) : 143-149. ISSN: 2328-7942 (Print); ISSN : 2328-7950 (Online)

Utami, S. Desmiwati. Endrinaldi. (2013). Faktorfaktor yang Berhubungan Dengan Unmet Need KB Pasca-Salin IUD post-plasenta di Kamar Rawat Pasca-Bersalin RSUP DR. M. Djamil periode Januari-Maret 2013. Jurnal Kesehatan Andalas 2 (3) : 158-163
World Health Organization. (2013). Programming Strategies for Postpartum Family Planning. Geneva : World Health Organization. 